\title{
TRANSFORMASI BUDAYA ORGANISASI OTORITAS PERPAJAKAN INDONESIA MENGHADAPI ERA EKONOMI DIGITAL
}

\author{
TRANSFORMATION OF ORGANIZATION CULTURE OF INDONESIA TAX AUTHORITY IN FACING \\ DIGITAL ECONOMY ERA
}

\author{
Maria R.U.D. Tambunan ${ }^{* 1}$ dan Rozan Anwar ${ }^{* *}$ \\ *) Departemen Ilmu Administrasi Fiskal, Fakultas Ilmu Administrasi, Universitas Indonesia \\ Jl. Prof. Dr. Selo Soemardjan, Depok 16424 \\ **) Daya Dimensi Indonesia \\ Jl. Mega Kuningan Barat Jakarta Selatan, 12950
}

\begin{abstract}
This article aimed to exemplify the dynamic transformation stages of Indonesia Tax Authority's shared values since the beginning of tax administration reform in 1983 until today, specifically in facing digital economic era. This article also aimed to comprehensively explain the dynamics of shared values followed by organization structural changes embedded to the shared value transformation. At the end, the shared-values are reflected to the readiness of Indonesia Tax Authority to face the challenges in tax business in this digital era. This research adopted constructivist paradigm with a qualitative research method. The techniques of data collection were literature reviews, documentation studies, and indepth interview. The research showed that Indonesia Tax Authority has made shared-value transformation in an incremental pattern. On the other hand, the organization structural changes and supporting infrastructure to implement core business transformation have been quite progressive. Besides, changes in leadership have not been transformative. Therefore, it needs serious measure to internalize shared-values vividly on daily activities and to transform the leadership style.
\end{abstract}

Keywords: shared-value, digital economy, tax administration, tax authority

\begin{abstract}
Abstrak: Artikel ini membahas mengenai dinamika perubahan budaya organisasi otoritas pajak Indonesia, Direktorat Jenderal Pajak sejak masa reformasi 1983 hingga masa terkini dalam menghadapi era ekonomi digital. Selain itu, perubahan budaya organisasi dari masa ke masa yang diikuti dengan perubahan struktur organisasi sejak dilaksanakannya reformasi perpajakan pada tahun 1983 akan dibahas dengan komprehensif sebagai acuan untuk memahami dinamika perubahan budaya yang telah dilaksanakan. Pada akhirnya perubahan budaya ini dihadapkan pada kesiapan institusi perpajakan dalam menghadapi tantangan pemajakan atas dinamika kegiatan entitas bisnis. Penelitian ini menggunakan paradigma kontruktivis dengan metode penelitian kualitatif. Teknik pengumpulan data dilakukan dengan studi literatur, studi dokumentasi serta wawancara mendalam. Hasil penelitian menunjukkan bahwa perubahan budaya organisasi terjadi di Direktorat Jenderal Pajak, namun bersifat incremental, berbeda dengan perubahan struktur organisasi dan infrastruktur pendukung pelaksanaan core business yang demikian progresif. Selain itu, perubahan gaya kepemimpinan juga masih belum bersifat transformatif. Dengan demikian, upaya untuk menginternalisasikan budaya organisasi yang telah diciptakan menjadi nilai-nilai bersama dalam kegiatan sehari-hari serta perubahan gaya kepemimpinan yang transformative masih sangat diperlukan.
\end{abstract}

Kata kunci: shared-value, ekonomi digital, administrasi pajak, otoritas pajak

\footnotetext{
${ }^{1}$ Corresponding author:

Email: maria.tambunan@ui.ac.id
} 


\section{PENDAHULUAN}

Hadirnya teknologi sebagai tulang punggung kegiatan bisnis pada era digital menjadikan suatu entitas dapat mengatur dan mendesain pola supply chain dan value creation-nya diberbagai jurisdiksi, tetapi tetap terintegrasi. Hal ini pulalah yang menjadikan batas geografis menjadi kabur, tidak tersekat dan semakin tidak berartinya jarak antar lokasi kegiatan ekonomi dalam satu kelompok entitas bisnis (IMF, 2015). Karateristik era digital yang disebut dengan industrialisasi 4.0 terdiri dari (Deloitte, 2015) (i) adanya integrasi hubungan vertikal dalam proses produksi (vertical networking of smart production system), (ii) adanya integrasi hubungan horizontal yang ditandai dengan strukturisasi pola supply chain (horizontal integration via a new generation of global value chain networks), (iii) adanya proses mekanisasi dalam keseluruhan supply chain (through-engineering across the entire value chain), (iv) akeselerasi kegiatan ekonomi yang didorong oleh perkembangan teknologi (acceleration through exponential technology).

Secara spesifik, tantangan terkini yang dihadapai otoritas pajak Indonesia adalah bagaimana mengenakan pemajakan atas kegiatan perdagangan elektronik (e-commerce) yang berkembang dengan sangat pesat dengan upaya yang efektif. Berdasarkan informasi dari Kementerian Keuangan, pada tahun 2017 hingga 24,7 juta penduduk di Indonesia melakukan pembelian melalui elektronik. Tentu, sejumlah online markeplace semakin menjamur dimana moda transaksi melalui elektronik semakin diminati oleh masyarakat. Pada tahun 2018, nilai perdagangan e-commerce Indonesia berada peringkat 6 di kawasan Asia Pasifik dengan pertumbuhan sebesar US $\$ 10,92$ miliar atau setara dengan Rp147,4 triliun. Selain itu, berdasarkan analisis Badan Kebijakan Fiskal menyebutkan bahwa penjualan online mengambil porsi penjualan retail sebesar 3,5\% pada 2017 dan akan mencapai 4,8\% pada 2019. Selain itu, terdapat pula berbagai jenis usaha yang menjalankan kegiatan bisnisnya di Indonesia tanpa kehadiran fisik seperti yang dilakukan oleh Google, Facebook, Yahoo. Pemerintah, terutama otoritas keuangan melihat bahwa terdapat potensi pemajakan yang cukup besar atas kegiatan transaksi elektronik tersebut.

Dengan perkembangan dunia digital yang kian cepat dan dinamis, adanya potensi kehilangan penerimaan negara dari sektor perpajakan (tax potential loss), potensi untuk melakukan agresive tax planning bahkan penghindaran pajak cenderung akan semakin tinggi. Hal ini menjadi tugas besar organisasi otoritas pajak untuk memastikan bahwa pajak yang dibayarkan adalah wajar sesuai dengan alokasi keuntungan yang seharusnya diterima oleh bagian dari suatu entitas binis multinasional. Oleh karena itu, otoritas pajak Indonesia harus melakukan transformasi serta meninggalkan budaya business-as-usual, mengingat peran vitalnya sebagai organisasi yang berperan dalam menghimpun penerimaan negara.

Berbagai penelitian terdahulu terkait isu-isu perpajakan pada umumnya memfokuskan pada bagaimana memformulasikan ketentuan dan regulasi terkait peningkatan kepatuhan dengan berbagai upaya seperti penegakan hukum (law enforcement) (Leviner, 2008; Tanko, 2015), diseminasi pengetahuan perpajakan kepada masyarakat (Mukhlis et al. 2015; Wong, 2015) berbagai diskursus terkait penghindaran pajak berikut berbagai upaya untuk melakukan penangkalan terhadap praktik penghindaran pajak tersebut (Rahayu, 2010; Chuenjit, 2014; Lipniewicz, 2017; Adoe dan Tambunan, 2018). Namun, penelitian dan diskursus terkait bagaimana transformasi institusi otoritas pajak yang dimotori oleh perubahan budaya organisasi dan kepemimpinan dengan memperhatikan konteks hadirnya era ekonomi digital sebagai faktor penting belum cukup masif. Salah satu aspek penting dalam transformasi organisasi adalah adanya transformasi budaya dan adanya kepemimpinan yang kuat dalam menghadirkan budaya yang baru adaptable dengan dinamika ekonomi. Hal ini pulalah yang menjadi keterbaharuan (state of the art) dalam artikel ini, dimana aspek budaya organisasi menjadi penting dan vital dalam menjalankan institusi otoritas pajak, tidak sekedar memformulasikan ketentuan formal dan material yang selama ini menjadi fokus-fokus penelitian. Terbentuknya platform administrasi pajak yang baik tidak terlepas dari aspek budaya yang transformatif yang didukung oleh kemampuan leadership yang baik yang dimiliki oleh pimpinan organisasi. Artikel ini membahas dinamika perubahan budaya organisasi otoritas pajak Indonesia, Direktorat Jenderal Pajak sejak masa reformasi 1983 hingga masa terkini dalam menghadapi era ekonomi digital. Selain itu, perubahan budaya organisasi dari masa ke masa yang diikuti dengan perubahan struktur organisasi sejak dilaksanakannya reformasi perpajakan pada tahun 1983 akan dibahas dengan komprehensif sebagai acuan untuk memahami dinamika perubahan budaya yang telah dilaksanakan. Pada akhirnya perubahan budaya 
ini dihadapkan pada kesiapan institusi perpajakan dalam menghadapi tantangan pemajakan atas dinamika kegiatan entitas bisnis.

\section{METODE PENELITIAN}

Pendekatan yang digunakan dalam penelitian ini adalah pendekatan kualitatif. Pendekatan kualitatif adalah suatu pendekatan dalam melakukan penelitian yang berorientasi pada gejala-gejala yang bersifat alamiah karena orientasinya demikian, maka sifatnya naturalistik dan mendasar serta tidak dapat dilakukan di laboratorium konvensional, melainkan harus terjun ke lapangan. Pendekatan ini bertujuan memberikan pemahaman dan interpretasi mengenai suatu fenomena sosial dengan cara observasi secara langsung. Salah satu karakteristik penelitian dengan pendekatan kualitatif adalah tidak bebas nilai, dengan artian dalam proses penelitian dapat dipengaruhi oleh berbagai nilai dan pendapatan subjektif. Lebih lanjut, teori yang digunakan dalam pendekatan ini bukan menjadi hal yang sentral, melainkan hanya sebagai dasar kerangka pemikiran untuk melakukan proses analisis data-data berdasarkan temuan di lapangan. Dengan demikian, teori tidak menjadi bahan verifikasi karena hanya bersifat penunjang dalam proses analisis ketika turun lapangan.

Penelitian ini dilakukan dalam kurun waktu sejak Maret 2017 hingga Mei 2018 dengan lokasi penelitian di Kantor Pusat Direktorat Jenderal Pajak. Pemilihan kantor Pusat Direktorat Jenderal Pajak merupakan pilihan satu-satunya lokasi penelitian dan menjadi lokasi terpenting ketika meneliti perubahan budaya organisasi otoritas pajak terkait dengan perubahan budaya dalam menghadapi era ekonomi digital karena pengelolaan budaya dalam instansi tersebut dilakukan oleh Kantor Pusat Direktorat Jenderal Pajak. Apabila ditinjau dari segi tujuan, penelitian ini termasuk dalam penelitian yang bersifat deskriptif. Penelitian deskriptif adalah penelitian yang secara detail menggambarkan fenomena atau gejala sosial yang sedang terjadi. Berkaitan dengan pengertian tersebut, tujuan penelitian ini adalah untuk menggambarkan sejauh mana transformasi budaya organisasi telah dilakukan oleh otoritas pajak dalam menghadapi era ekonomi digital berikut dengan halhal yang berhubungan dengan transformasi tersebut. Teknik pengumpulan data dilakukan menggunakan teknik pengumpulan data kualitatif, yaitu melalui studi literatur, studi dokumentasi serta wawancara mendalam.
Data yang dikumpulkan terdiri dari data primer dan data sekunder. Data primer terdiri dari interview dengan key informant, sementara data sekunder berasal dari berbagai berbagai informasi publikasi oleh instansi otoritas pajak Indonesia, konsultan pajak dan media massa.

Penelitian ini menggunakan kerangka pemikiran dengan mengambil otoritas pajak Indonesia, Direktorat Jenderal Pajak sebagai obyek penelitian dengan berdasarkan pertimbangan bahwa institusi tersebut bertugas untuk mengumpulkan penerimaan negara yang berasal dari pajak, dimana lebih dari $70 \%$ penerimaan negara berasal dari perpajakan. Hadirnya era digital menjadikan kegiatan bisnis semakin dinamis, tidak tersekat oleh jurisdiksi dan semakin mobile dan isu stateless revenue semakin menguat. Ketika isu ekonomi digital belum cukup marak, institusi perpajakan terus diperhadapkan dengan target penerimaan yang meningkat setiap tahunnya. Dengan hadirnya ekonomi digital, hal tersebut akan menjadi tantangan baru bagi institusi perpajakan untuk mampu mengumpulkan penerimaan yang berkesinambungan ditengah tantangan yang telah ada sebelumnya. Perubahan budaya organisasi merupakan aspek penting yang perlu diupayakan ditengah perjalanan reformasi perpajakan Indonesia. Adapun kerangka pemikiran terkait isu tersebut dalam penelitian ini dapat digambarkan pada Gambar 1.

\section{HASIL}

\section{Budaya Organisasi dan Kepemimpinan}

Mendefinisikan budaya organisasi bukanlah suatu hal yang mudah karena budaya organisasi lahir dalam sebuah konteks kultural yang sangat luas (Willcoxson dan Millet, 2000). Sebelumnya, oleh Willcoxon dan Millet mengutip beberapa definsi budaya, yaitu sebagai suatu basis yang membentuk persepsi dan perilaku sekelompok orang yang akhirnya menjadi nilai bersama (Benedict, 1934; Kluckhohn dan Strodtbeck, 1961), identitas kolektif dari sekelompok orang (Trice dan Beyer, 1993). Sementara, budaya organisasi didefinisikan sebagai seperangkat norma, belief, prinsip, dan pedoman dalam berperilaku yang dilaksanakan secara kolektif dimana hal tersebut menjadi karakteristik tertentu dari suatu organisasi. Budaya organisasi juga menentukan bagaimana suatu organisasi memberikan perhatian atas suatu hal dan bagaimana berespon dan melakukan adaptasi terhadap 
lingkungan eksternal dengan berbagai dinamikanya. Dalam membentuk budaya dalam suatu organisasi, Willcoxson dan Millet (2000), mengutip (Schein, 1991) bahwa perlu memperhatikan hal-hal berikut: (i) adanya dasar dari pembentukan basis asumsi bersama, (ii) dasar yang dibentuk tersebut ditemukan, dikembangkan oleh suatu kelompok, (iii) dasar tersebut menjadi dasar organisasi ketika diperhadapkan dalam suatu tantangan dalam integrasi internal maupun dinamika lingkungan eksternal, (iv) dasar yang diinternalisasikan keseluruh anggota organisasi, (v) menjadi pedoman koreksi atas persepsi, pemikiran, hubungan antar personal ketika menghadapi berbagai tantangan.

MenurutPeterSenge(1990) visibersama (shared vision) yang tidak lain adalah budaya organisasi merupakan hal yang sangat penting dalam sebuah organisasi karena adanya visi yang dimiliki bersama, akan mendorong anggota organisasi bersedia berkontribusi mencapai tujuan bersama dalam organisasi. Lebih lanjut, Senge menyebutkan bahwa shared vision tersebut yang membuat anggota organisasi mampu bekerja sama, terutama ketika organisasi menghadapi tantangan, terutama dari lingkungan eksternal. Visi bersama menciptkan identitas bersama, yaitu tingkatan paling mendasar dari kesamaan sesama anggota organisasi. Brown (1998) menyebutkan sedikitnya ada lima fungsi budaya organisasi, yaitu (i) mengurangi konflik internal, (ii) koordinasi dan pengawasan (iii) mengurangi ketidakpastian, (iv) memotivasi dan (v) mendorong terjadinya keunggulan kompetitif.

Ketika membentuk suatu budaya organisasi, hal penting yang perlu diperhatikan adalah bagaimana menerjemahkan budaya yang akan diinjeksi kedalam suatu organisasi. Penetrasibudaya tersebut diimplementasikan kedalam strategi organisasi, kemudian strategi tersebut seoptimal mungkin menjadi bagian dari perilaku sehari-hari yang dapat diukur serta berpenetrasi dalam setiap aktivitas di masing-masing lini organisasi. Suatu budaya yang telah diciptakan dan dibangun bersama akan dapat secara efektif diimplementasikan oleh pemimpin yang memiliki kemampuan (skill) kepemimpinan yang baik.

Dalam menghadapi era digital, kesuksesan suatu organisasi ditopang oleh budaya yang dianutnya. Publikasi yang dilakukan Mc. Kinsey menunjukkan bahwa untuk mampu memenangkan berbagai tantangan, digital culture yang harus dimiliki oleh suatu organisasi minimum harus meliputi: (i) memahami dengan baik masing-masing fungsi yang dijalankan sebagai bagian dari suatu organisasi, (ii) keberanian untuk mengambil peluang dan risiko, serta (iii) bertindak dengan menggunakan sudut pandang customer (Goran et al. 2017).

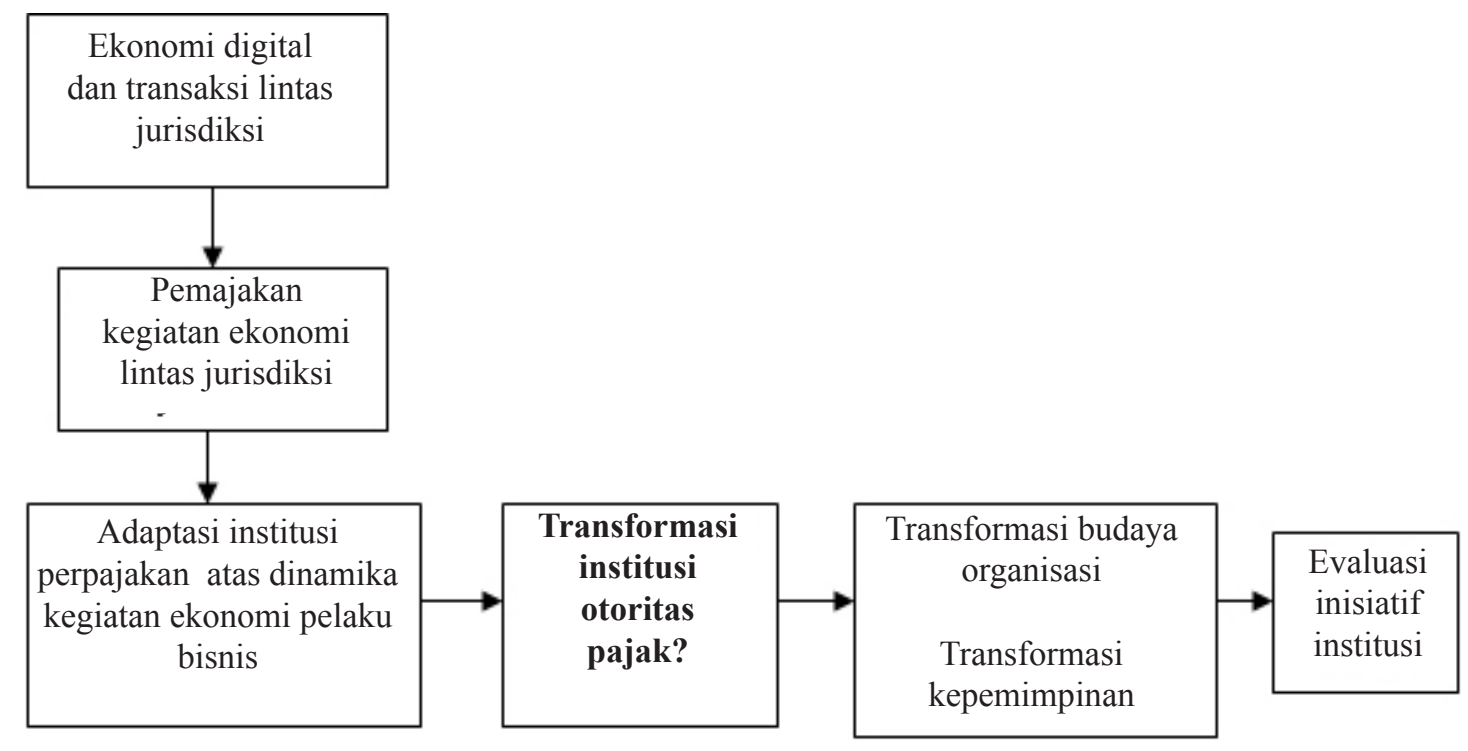

Gambar 1. Kerangka pemikiran penelitian 
Terkait kepemimpinan dalam suatu organisasi, mengutip Peter Drucker "Leadership is about lifting a person's vision to higher sights, the raising of a person's performance to a higher standard, the building of a personality beyond its normal limitations". Dalam aspek kepimipinan melekat sebuah visi yang menarik orang lain untuk bergerak menuju standar terbaik. Seorang pemimpin yang memiliki kemampuan kepemimpinan yang baik dapat diartikan bahwa dalam setiap tindakan pemimpin tersebut melekat nilai, belief dan asumsi yang menjadi budaya dari organisasi yang dipimpinnya. Gaya kepemimpinan juga berpengaruh terdahap komitmen organisasi (Fabio et al. 2016) Dalam menginternalisasikan budaya organisasi, pemimpin harus mampu membuat suatu arahan serta melakukan eksekusi. Perumusan arahan diawali dengan mendefinisikan budaya yang telah dipilih (selected culture) dan mengartikulasikannya kepada seluruh anggota organisasi melalui prinsip dan nilai. Kemudian, pada tahap eksekusi, pemimpin organisasi melakukan sosialisasi atas indentitas organisasi dengan komunikasi yang jelas dan mudah dipahami, melakukan monitoring terhadap tingkat penetrasi budaya, melakukan feedback, dan coaching. Selanjutnya, pada tahap reinforcing budaya diperlukan adanya upaya alignment terhadap tujuan organisasi, proses pencapaian tujuan terhadap identitas dan nilai organisasi melalui evaluasi performa anggota organisasi, kompensasi yang sesuai, promosi yang tepat serta adanya reward/punishment.

\section{Perubahan Budaya Organisasi dan Kepemimpinan Institusi Perpajakan Indonesia dalam Menghadapi Kegiatan Ekonomi Digital}

Pada dasarnya, dengan adanya pola digitalisasi, terdapat berbagai kesempatan yang dapat dimanfaatkan oleh pelakubisnis seperti peningkatan produktivitas, semakin mudahnya melakukan inovasi, semakin meningkatnya mobilitas global termasuk dalam hal distribusi barang dan jasa, semakin rendahnya marginal cost dan semakin efisiennya struktur suatu entitas bisnis. Natur bisnis terkini yang semakin mengoptimalkan pola digitalisasi, fragmentasi usaha merupakan tantangan besar bagi organisasi otoritas perpajakan untuk melakukan pengawasan apakah jumlah kewajiban pajak yang dibayarkan ke kas negara telah sesuai dengan besaran sebagaimana seharusnya.
Organisasi otoritas pajak di suatu negara, termasuk Indonesiasepantasnya mampumengikutiperkembangan dan dinamika kegiatan ekonomi entitas bisnis. Transformasi administrasi pajak dalam menghadapi era digital merupakan salah satu tantangan besar karena selain adanya kebutuhan internal untuk bertransformasi mengikuti pola bisnis para pelaku usaha, berbagai faktor eksternalpun merupakan faktor penekan untuk segara melakukan berbagai perubahan dan adaptasi. Faktor eksternal seperti kewajiban untuk menghimpun penerimaan negara yang lebih besar dengan mencari basis pemajakan baru dimana terdapat berbagai potensi sumber penerimaan akibat berkembangnya kegiatan ekonomi digital merupakan tantangan dan peluang yang dihadapi otoritas pajak (Lipniewicz, 2017).

Selain itu, terdapat berbagai konsensus global terkait guideline pemajakan kegiatan ekonomi lintas jurisdiki yang disepakati bersama dalam naungan organisasi internasional seperti OECD dan UN (adapun konsensus dalam bentuk guidelineseperti Base Erosion and Profit Shifting (BEPS) Action Plan, Common Reporting Standard, Automatic Exchange of Information) untuk diimplementasikan dalam sistem perpajakan domestiknya. Berbagai fenomena diatas menginginkan adanya aligment antara kegiatan ekonomi entitas bisnis sebagai wajib pajak yang semakin terdigitalisasi dengan pola pelayanan perpajakan, yaitu pelaksanaan hak dan kewajiban timbal balik.

Mengutip pendapat Stig Sollund (2018) dari interview Vissaro (2018) kemudian dipublikasikan oleh Danny Darussalam Tax Centre (2018) mengatakan bahwa digitalisasi merupakan proses yang akan berlangsung secara terus menerus. Bagi otoritas pajak, hal ini akan mempengaruhi bagaimana kegiatan bisnis dapat dikenakan pajak secara efisien, terlebih dimana praktik penggeseran keuntungan dengan berbagai skema seperti transfer pricing (Huda dan Kamaruddin, 2017). Sollund juga menekankan bahwa peraturan perpajakan perlu adaptable dengan perubahan dan dinamika bisnis, tidak semata-mata agar penerimaan negara terjamin dari potensi-potensi kegiatan ekonomi yang kian berkembang, namun perlu secepatnya untuk memberikan kepastian terhadap pelaku bisnis mengenai kewajiban perpajakan dan beban pajak yang mereka harus penuhi. 
Salim (2014) dalam bukunya berjudul Exponential Organization (ExO) menekankan bahwa perlunya meninggalkan pola dan budaya tradisional menuju ExO jika ingin tetap survive dalam era disrupsi terkini. Pendekatan tradisional tersebut berupa masih dipertahankannya berbagai kegiatan pemecahan masalah dengan pola linear. Dalam suatu organisasi ExO, pengembangan organisasi dilakukan dengan mengoptimalkan sumber daya yang tidak harus dimiliki oleh organisasi, dalam arti menekankan pada efisiensi, mengoptimalkan data sebagai aset utama sebagai modal utama untuk melakukan transformasi dengan penggunaan teknologi yang optimal. Organisasi dibangun sebagai suatu institusi yang dinamis dan cepat tanggap terhadap ketidakpastian lingkungan eksternal. Tentu nilai yang demikian merubah pola kerja (engagement) organisasi menjadi semakin agile.

Meskipun Salim (2014) menguraikan pentingnya perubahan bagi organisasi sektor privat, namun konsep tersebutpun dapat diadopsi bagi organisasi sektor publik, mengingat dinamika ekonomi akibat hadirnya era disrupsi juga mempengaruhi organisasi sektor publik. Otoritas pajak merupakan organisasi sektor publik yang memiliki kompleksitas yang tinggi. Gunadi (2004) menyebutkan bahwa timbulnya berbagai jenis dan bentuk usaha, berbagai perjanjian bilateral, multilateral serta global menjadi tantangan besar yang dihadapi oleh otoritas pajak seraya menjalankan fungsinya. Memahami kompleksitas inilah yang menjadi tantangan sekaligus faktor pembentuk perubahan budaya administrasi pajak di era disrupsi saat ini.

Sebelumnya, penelitian yang dilakukan oleh Nurmantu (2008) menyebutkan bahwa terdapat 4 fase perubahan budaya di organisasi otoritas perpajakan Indonesia, Direktorat Jenderal Pajak (DJP). Fase pertama (1983/1984) sebelum masa reformasi awal yaitu nilai-nilai yang berdasarkan kekuasaan (superioritas) untuk melakukan penaksiran terhadap beban pajak dan kedudukan wajib pajak diposisikan pada posisi inferior. Fase kedua (1983-hingga reformasi 1994), terdapat perubahan superioritas posisi petugas pajak, namun pada saat pemeriksaan kewajiban perpajakan belum didasarkan pada prinsip keadilan/kesetaraan serta pelayanan terhadap wajib pajak belum didasarkan pada nilai-nilai pelayanan prima. Selain itu, terdapat nilai otokrasi dalam bentuk peraturan perpajakan yang tidak sepenuhnya didukung oleh aspek filosofis pajak dan hukum serta ada kalanya mengabaikan prinsip keadilan demi mencapai target penerimaan.

Padafase ketiga (1995-hingga reformasi tahun 2000), pada fase ini, DJP sudah mulai menyadari pentingnya pelayanan yang baik terhadap wajib pajak, namun budaya lama masih terasa. Pada fase ini, pimpinan DJP juga sudah mulai menyadari perlunya untuk melakukan efisiensi terhadap pelaksanaan core business DJP. Beberapa artifact yang dihasilkan pada fase ini seperti berbagai jargon seperti "know your taxpayer!". Selanjutnya, pada fase keempat (2000-2008), DJP sudah diperkenalkan kepada budaya melayani dengan suatu standarisasi. Hal tersebut tercermin dari berbagai produk publikasi "committed to best services and high standard". Namun, terdapat berbagai fase perubahan budaya, budaya lama masih timbul, seperti masih belum seriusnya memberikan pelayanan terhadap masyarakat karena hal tersebut belum dianggap sebagai prioritas dan preferensi oleh sejumlah besar pegawai DJP. Pembentukan espouse value menjadi basic common underlying assumption hingga era reformasi fase ke empat dianggap belum optimal. Pada tahun 2010, nilainilai organisasi dicanangkan sebagai bentuk komitmen DJP terhadap pelaksanaan reformasi birokrasi. Adapun nilai-nilai tersebut adalah profesionalisme, integritas, teamwork dan inovasi yang disingkat "PasTI" (DJP, 2010).

Dalam konteks teknis struktur organisasi, adapun perubahan yang terjadi di lembaga Direktorat Jenderal Pajak dapat diuraikan sebagai berikut:

Pada awal masa reformasi perpajakan di Indonesia tahun 1983, penyusunan struktur organisasi didasarkan semata-mata pada jenis-jenis pungutan yang ada saat itu. Penentuan penyusunan struktur belum didasarkan pada pertimbangan yang kompleks dimana kegiatan transaksi ekonomi lintas jurisdiksi belum cukup masif. Dasar pembentukan struktur organisasasi diatur melalui Keputusan Presidium Kabinet No. 75/U/KEP/II/1966 tentang Struktur Organisasi dan Pembagian Tugas Departemen-Departemen. Saat itu terdapat 4 Direktorat dengan 1 Sekretaris Direktorat. 
Pada tahun 2000, reformasi administrasi perpajakan dilakukan yang pada akhirnya ditujukan untuk meningkatkan kepatuhan wajib pajak dan meningkatkan kepercayaan publik kepada DJP. Selain itu, reformasi pada masa ini juga merupakan salah satu respon dalam menghadapi krisis ekonomi yang terjadi sejak 1998. Pada fase ini, DJP berhasil meningkatkan penerimaan pajak, namun belum berhasil meningkatkan kepatuhan wajib pajak. Masih rendahnya kepatuhan wajib pajak tidak terlepas dari masih lemahnya otoritas pajak dalam hal pelaksanaan hukum dan jaminan kepastian hukum. Selain itu, kapasitas SDM juga masih perlu ditingkatkan sebagai motor perubahan budaya organisasi otokrasi di DJPyang seyogiyanya menjadi faktor penting dalam pecapaian tujuan reformasi (Putra, 2013). Organisasi DJP berkembang cukup pesat yang kemudian terjadi perubahan struktur organisasi, dimana terbentuk 8 unit Direktorat dengan 1 unit Sektretaris Direktorat, serta Kantor-Kantor Wilayan.

Pada dasarnya, sejak 2001 proses perubahan yang dilakukan oleh DJP diarahkan kepada perubahan organisasi, proses bisnis dan SDM. Dalam hal perubahan organisasi, terjadi evolusi desain organisasi dari semula desain berdasarkan jenis pungutan pajak, kemudian berubah menjadi berdasarkan fungsi kemudian berubahan menjadi berdasarkan pelayanan kepada wajib pajak. Organisasi dengan berbasis fungsi terlihat dengan dibentuknya Kantor Pelayanan Pajak dengan mengemban berbagai fungsi seperti fungsi pelayanan, fungsi pengawasan, fungsi konsultasi serta fungsi pemeriksaan. Selanjutnya, organisasi berdasarkan pelayanan terhadap wajib pajak terlihat dengan dibentuknya Kantor Pelayanan Pajak Khusus untuk wajib pajak tertentu. Unit kerja ini menangani Wajib Pajak Besar Nasional, Wajib Pajak Besar Wilayah, Penanaman Modal Asing, Badan dan Orang Asing, Perusahaan Masuk Bursa, Badan Usaha Milik Negara, Perusahaan Tambang serta Perusahaan Minyak Bumi dan Gas. Selain itu, DJP juga membentuk Kantor Penyuluhan, Pelayanan dan Konsultasi Perpajakan (KP2KP) (DJP, 2012).

Pada tahun 2006, konsep organisasi modern diperkenalkan. Selanjutnya sejak 2007 manajemen berbasis kinerja dengan menggunakan Balance Scorecard (BSC) diterapkan sebagai suatu upaya membangun budaya organisasi baru. DJP (2010) mempublikasikan bahwa kinerja DJP tidak hanya dilihat dari dari stakeholder perpective saja, yaitu terkait penerimaan pajak, tetapi juga dari customer perspective, internal process perspective serta learning and growth perpective. DJP juga telah membentuk sejumlah indikator terkait manajemen berbasis kinerja tersebut. Selain itu, dilakukan restrukturisasi organisasi DJP dimana terbentuk 14 unit Direktorat, 1 Pusat Pengolahan Data dan Dokumen Perpajakan, 1 Sekretariat Direktorat serta 4 Unit Tenaga Pengkaji.

Pada tahun 2009-2012, reformasi DJP difokuskan kepada modernisasi administrasi pajak dengan menggunakan teknologi informasi dalam menjalankan core business-nya dan baik dalam hal pengaturan internal. Pilihan penggunaan teknologi didasarkan kepada peningkatan efektifitas pelayanan terhadap wajib pajak serta penciptaan budaya transparan dalam hal manajemen SDM, sistem penggajian, pelatihan, uraian jabatan, kebijakan mutasi serta proses perekrutan. Pelaksanaan modernisasi ini dikenal dengan program PINTAR (Project for Indonesia Tax Administration Reform) yang pendanaannya sebagaian besar berasal dari pinjaman dari pihak World Bank sebesar USD 1,2 juta atau setara Rp. 1 triliun (kompas. com, 2010). Pada awalnya proyek ini direncanakan berakhir pada tahun 2014, namun terhenti sebelum masa pelaksanaan proyek selesai. Adapun tantangan dalam pelaksanaan program PINTAR adalah dimana proyek tersebut merupakan proyek TIK berskala besar yang membutuhkan penyelesaian lebih dari satu tahun sehingga memerlukan suatu kontrak multi years. Ketentuan domestik seperti Keppres No. 80 tahun 2003 sebagai dasar proses pengadaan proyek yang menggunakan dana APBN tidak mengatur kontrak multi years untuk proyek TIK. Untuk proyek yang didanai oleh World Bank, proses pengadaannya mengacu kepada World Bank Procurement yang memungkinkan adanya kontrak multi years untuk pengadaan proyek TIK. Total pendanaan proyek PINTAR kurang lebih USD 146 juta USD, dimana sekitar 75\% atau sekitar sebesar USD 110 juta USD dibiayai oleh pinjaman dari World Bank, sementara sisanya sebesar $25 \%$ atau setara sekitar USD 36 juta akan dibiayai oleh APBN (kompas. com, 2010). Pada tahun 2012, mempertimbangkan dinamika kegiatan ekonomi yang ada, DJP memiliki 14 unit Direktorat, 4 unit Tenaga Pengkaji, serta 1 unit Sekretariat Direktorat. 
Dengan uraian tersebut, dapat dilihat bahwa perubahan struktur organisasi di DJP telah berkembang dengan progresif yang seyogiyanya merupakan bentuk nyata dari terjadinya perubahan budaya yang kemudian mempengaruhi proses pelaksanaan kinerja dan karakteristik. Namun, apakah perubahan struktur organisasi tersebut merupakan konsekuensi dari terjadinya perubahan budaya di DJP,pada kenyatannya tidak demikian.Sejak dilaksanakannya reformasi perpajakan 1983, fokus dari misi reformasi tersebut belum bergerak dari membangun kepercayaan dari masyarakat serta memperbaiki sistem pelayanan kepada masyarakat (wawancara JPP dengan Direktur Jenderal Pajak, Robert Pakpahan, November 2017). Penelitian yang dilakukan Solikhatun (2010) juga menunjukkan bahwa tingkat kepercayaan masyarakat untuk membayar pajak juga masih sangat rendah sehingga pihak DJP masih harus memiliki tugas yang cukup besar untuk meyakinkan masyarakat. Demikian halnya penelitian yang dilakukan oleh Ratmono dan Cahyonowati (2016) mengenai kepercayaan masyarakat terhadap otoritas pajak, menunjukkan bahwa tingkat kepercayaan masyarakat belum cukup baik. Dalam penelitian tersebut diuraikan bahwa tingkat kepercayaan masyarakat akan meningkat jika otoritas pajak menjalankan sistem hukum dengan baik sehingga wajib pajak akan mematuhi peraturan perpajakan dengan sukarela. Selain itu, kegiatan audit yang masif yang dilakukan oleh DJP justru mendegradasi kepercayaan wajib pajak.

Saat ini, memasuki era digital, yang ditandai dengan pergeseran pola kegiatan bisnis menjadi tantangan sekaligus peluang bagi pemerintah. DJP diharapkan mampu mengikuti perubahan tersebut dengan melakukan transformasi terkait peningkatakan kualitas SDM yang ditopang oleh perubahan budaya organisasi dan kepemimpinan, struktur kelembagaan, pola kerja core-bisnis termasuk optimalisasi penggunan teknologi. Sebagai bentuk respon terhadap dinamika lingkungan, Kementerian Keuangan menyusun kembali tim reformasi melalui Keputusan Menteri Keuangan No. KMK-885/KMK.03/2016 yang bertujuan untuk melakukan perbaikan atas struktur organisasi dan peningkatan kualitas SDM, optimasi IT dan penghimpunan basis data terkait transformasi bisnis dan peningkatan kualitas peraturan perundangundangan. Hal ini diharapkan mampu menciptakan budaya baru untuk meningkatkan kepercayaan Wajib Pajak terhadap insitusi perpajakan, kepatuhan wajib pajak, kehandalan pengelolaan administrasi pajak dan integritas serta produktivitas petugas pajak. Program perbaikan tersebut dirumuskan adalah Insiatif Program Transformasi Kelembagaan DJP pada Tabel 1.

Inisiatif pada Tabel 1 menunjukkan bahwa telah DJP menyadari perlunya perubahan budaya yang memudian menjadi dasar untuk melaksanakan misi dari fungsi pemungutan pajak, yaitu budgeter (mengumpulkan penerimaan negara dari sektor perpajakan) dan regulerend (menggunakan pajak sebagai instrumen social and economic engineering) yang mengedepankan bekerja secara profesional dan efisien yang diturunkan ke dalam 9 visi, kemudian dijabarkan ke dalam berbagai bentuk inisiatif dan obyektif. Dalam menghadapi era digital, inisiatif yang merupakan penjabaran dari budaya baru tersebut menunjukkan perlunya strategi tertentu dalam penjangkauan wajib pajak termasuk terkait strategi audit, konsistensi penegakan hukum, kolaborasi dengan berbagai lembaga lain terkait penghimpunan data, optimasi penggunaan IT dan bagaimana IT tersebut digunakan sebagai tulang punggung dalam menjalankan aktivitas core business DJP. Selain itu, peningkatan kualitas SDM yang merupakan hasil dari pembentukan budaya baru dalam menghadapi era ekonomi digital di lingkungan DJP juga merupakan salah satu agenda dalam inisiatif ini dan memperkuat struktur organisasi.

Penggunaan IT yang optimal merupakan langkah maju dalam menghadapi era digital, namun perubahan budaya organisasi merupakan hal penting lainnya yang justru menjadi motor dalam kesiapan menghadapi perubahan yang ada. Bercermin dari perubahanperubahan yang pernah dilakukan sejak masa reformasi 1983, DJP melakukan perubahan progresif dalam hal perangkat struktur organisasi dengan bertambahnya jumlah unit kerja struktural dan fungsional yang kemudian diharapkan berkembang menjadi suatu badan baru yang bersifat semi otonom serta memiliki fleksibilitas yang tinggi (Setyowati et al. 2016; James, 2016), perubahan infrastruktur, namun perubahan dalam aspek kualitas SDM tidak seprogresif perubahan struktur dan infrastruktur yang telah dilakukan. Hal ini pada akhirnya akan berdampak pada aspek kepatuhan (Farida, 2017) 


\begin{tabular}{ll}
\hline Misi & Inisiatif \\
\hline Menggeser & Meningkatkan segmentasi \\
tax mix untuk & wajib pajak dan coverage \\
mengikutsertakan & model \\
semua wajib & Menjangkau ekonomi \\
pajak & $\begin{array}{l}\text { informal melalui } \\
\text { pendekatan end-to-end }\end{array}$ \\
& Membenahi sistem \\
& administrasi PPN \\
Menegakkan & Mengembangkan model \\
kepatuhan & kepatuhan yang prediktif, \\
berbasis resiko & berbasis-risiko terkait \\
& dengan proses bisnis \\
& Meningkatkan efektifitas \\
& pemeriksaan dan \\
& penagihan \\
Meningkatkan & Memastikan kualitas \\
integritas & konsistensi penegakan \\
penegak hukum & hukum
\end{tabular}

\section{Mendapatkan efek tidak langsung lewat integrasi komunikasi \\ Meluncurkan strategi komunikasi}

Memperkuat kemitraan eksternal

Implementasi opeasi

"learn" dan elektronifikasi end-to-end

Bergeser ke model layanan multi-channel

Memperkuat human capital

Memberdayakan organisasi

Secara sistematis untuk data, penegakan wajib pajak jangkauan DPC dan perolehan data e-filing

Secara drastis call centre

Memperluas fungsionalitas website selektif meningkatkan kapasitas Obyektif

Menjangkau UKM secara efektif dengan menyempurnakan segmentasi dan membenahi coverage model

Mengakses ekonomi informal dengan memprioritaskan sektor informal dengan potensi pajak tertinggi dan mengkoordinasi pendekatan end-to-end si seluruh Kanwil DJP

Optimalisasi penerimaan PPN dengan meningkatkan kepatuhan

Memungkinkan DJP Mencapai obyektif strategisnya dengan memfasilitasi manajemen agar mengambil keputusan yang lebih baik

Meningkatkan audit coverage ratio dan mengurangi total durasi pemeriksaan serta meningkatkan efektivitas penagihan dan menyasar wajib pajak penunggak dengan lebih baik.

- menyusun proses kepatuhan internal yang bertarget dan standar guna meningkatkan kualitas dan meminimalkan variasi dalam proses penegakan hukum

- memastikan konsistensi informasi dan penanganan diseluruh pemeriksaan, penyidikan awal, keberatan, banding dan penyidikan

- meningkatkan kepatuhan dengan melaksanakan penyuluhan wajib pajak dan mempublikasikan penegakan pajak

- memperbaiki citra DJP dengan melakukan komunikasi tentang upaya transformasi dan secara proaktif mengelola isu-isu eksisting melibatkan pihak ketiga hukum dan penjangkauan

Menyempurnakan KPP

Membangun dan memperkuat kemitraan eksternal dalam distribusi data, penjangkauan wajib pajak dan penegakan hukum untuk meningkatkan penerimaan dan meningkatkan kepatuhan

- menjalankan transformasi layanan frontline di KPP

- efisiensi sistem pemrosesan dokumen dengan menerapkan learn principle di KPP

Secara efektif memperluas meningkatkan kapabilitas

Migrasi wajib pajak ke meningkatkan kapasitas

Menyelaraskan kembali staff fungsional dan secara

Restrukturisasi organisasi - memperluas peranan DPC dalam mendukung digitalisasi dokumen di DJP

- memperbaiki kecepatan, akurasi dan keamanan dalam proses SPT

- meningkatkan dan memperluas kapabilitas IT dalam pelaporan SPT untuk mengurangi beban kerja administratif DJP

- meningkatkan kesadaran dan kepercayaan dari wajib pajak untuk meningkatkan tingkat penggunaan e-filing

- mengembangkan contact centre yang menyediakan akses multi-channel dengan layanan yang diperluas dengan dwi-bahasa, integrasi dengan website Dirjen Pajak dan kapasitas outbound

- mengembangkan website yang user friendly, cepat dan mudah diakses

- memperbaiki/meningkatkan fitur layanan dan penyuluhan

- memperjelas peranan fungsional AR dan membuat peranan atau bagian yang menangani fungsi layanan atau pemeriksaan

- mengindetifikasi kebutuhan khusus untuk kapasitas yang meningkat dan cara meningkatkan peranan fungsional secara selektif

- memperkenalkan layar eselon 1B untuk mengurangi span of control

- agregasi fungsi sejenis (misalnya, unit transformasi) dan memperkenalkan unit baru untuk kapabilitas yang diperlukan (misalnya, intelijen bisnis, quality assurance)

Menjamin adanya otonomi • secara selektif menegosiasi fleksibilitas di bidang SDM, organisasi dan anggaran yang diperlukan untuk transformasi
- meminta persetujuan agar DJP menjadi lembaga semi otonom 
Selain itu, perlu ditekankan pula bahwa obyektif Inisiatif Program Transformasi Kelembagaan Direktorat Jenderal Pajaktersebut akan dapat dicapai apabila diterjemahkan ke dalam berbagai program yang outcomesnya terukur serta dipimpin oleh pimpinan yang memiliki kemampuan leadership yang baik. Komite Pengawas Perpajakan (Komwas Pajak) menggarisbawahi bahwa tantangan terbesar dari setiap pemimpin organisasi DJP adalah konsistensi menjalankan pemungutan pajak yang berdasarkan pada prinsip keadilan bagi wajib pajak (antar wajib pajak baik WP besar, WP pengusaha kecil atau orang pribadi) dan petugas pajak dalam memenuhi target penerimaan. Disisi lain, Apindo (2017) melihat bahwa kualitas kepimpinan DJP sudah mengalami peningkatan secara umum dari masa ke masa. Namun, masih diperlukan keterbukaan terutama terkait penyampaian masukan dari kalangan pelaku usaha dan masyarakat.Selain itu, dalam ruang lingkup yang lebih spesifik, terkait gaya kepemimpinan di kantor Pusat DJP dalam konteks gaya kepemimpinan transformasional, transaksional dan laissez-faire, dalam suatu penelitian menunjukkan bahwa kepemimpinan di kantor Pusat DJP cenderung masih menggunakan gaya kepemimpinan laissez-faire, dengan kepuasan kerja pegawai DJP yang cukup tinggi terhadap jenis kepemimpinan yang demikian (Yulianto dan Hartijasti, 2014).

Melihat kembali perjalanan reformasi DJP, pada dasarnya telah terjadi berbagai perubahan budaya organisasi yang berlangsung secara incremental. Diperlukan monitoring dan evaluasi yang berkelanjutan untuk memastikan bahwa budaya organisasi yang diharapkan semakin berpenetrasi menjadi shared value organisasi, yang kemudian menjadi dasar berperilaku sehari-hari. Tentu saja hal ini dimotori oleh pemimpin yang memiliki gaya kepemimpinan transformasional, tidak sekedar laissez-faire.Proxy yang paling sederhana yang dapat digunakan sebagai evaluasi terkaitperubahan budaya organisasi dan kepemimpinan, selain tax ratio sebagai parameter kuantitatif, adalah tingkatansemakin positifnya persepesi wajib pajak terhadap kinerja DJP. Hingga saat ini, jika dilihat kembali terkait persepsi masyarakat terhadap kinerja DJP berbagai penelitian menunjukkan bahwa (Hadini et al. 2012; Widia, 2017) masih perlu melakukan berbagai upaya untuk mendapatkan kepercayaan dari masyarakat.

\section{Implikasi Manajerial}

Fenomena digitalisasi ekonomi merupakan tantangan yang tidak dapat dihindarkan oleh otoritas pajak, dimana penyesuaian pelaksanaan core business otoritas pajak sudah harus mengikuti pola aktivitas pelaku bisnis. Adanya modernisasi dengan penetrasi teknologi dalam pelaksanaan kegiatan sehari-hari untuk mempermudah pekerjaan dan perubahan struktur organisasi adalah hal yang positif. Namun, transformasi organisasi otoritas pajak dengan adanya perubahan budaya organisasi yang adaptable dengan lingkungan sekitar dan terbentuknya organisasi yang bersifat pembelajar (learning organization)merupakan hal lain yang membedakan organisasi tradisional dan organisasi modern. Dalam hal pembentukan organisasi modern, mengutip Peter (2006) bahwa aspek penting yang harus dimiliki organisasi modern sehingga adaptable dengan lingkungan sekitar adalah (i) adanya sistem thinking merupakan pemersatu (bounding) terhadap pengetahuan yang saling terinterelasi, yang berada di dalam organisasi, (ii) personal mastery; "shared vision emerge from personal vision", (iii) mental model; merupakan suatu penanaman yang mendalam mengenai penggambaran bagaimana memahami kompleksitas dan dinamika dunia serta bagaimana seharusnya individu dapat menyikapi dan mengambil langkah sebagai respon. Pada umumnya, seorang individu sering tidak menyadari bagaimana mental modelnya atau bagaimana sesuatu hal akan berdampak bagi perilakunya, (iv) building shared vision; jika suatu ide mengenai leadership mampu mengispirasi organisasi untuk kurun waktu yang sangat panjang, hal tersebut merupakan suatu bentuk kapasitas yang mampu menciptakan suatu nilai dan tujuan bersama, dan (v) team learning; ketika suatu tim benar-benar melakukan pembelajaran, sebagai outcomes yang diperoleh bukanlah semata-mata hasil yang sangat baik. Namun, anggota organisasi akan bertumbuh lebih cepat dari yang biasa.

Ketika suatu organisasi melakukan transformasi budaya yang mengarah kepada perwujudan learning organization, terutama agar mampu menghadapi dinamika bisnis di era digital. Hal-hal berikutmerupakan aspek penting yang perlu diperhatikan oleh otoritas pajak Indonesia seperti: (i) pembentukan budaya organisasi didasarkan pada knowledge manajemen, (ii) meningkatkan kecepatan inovasi dengan melibatkan 
antar lini dalam organisasi otoritas pajak, (iii) mengatasi kendala teknis sedini mungkin, (iv) mengupayakan respon yang cepat terhadap keluhan wajib pajak, (v) mengupayakan layanan yang menjadi concern wajib pajak.

\section{KESIMPULAN DAN SARAN}

\section{Kesimpulan}

Budaya organisasi merupakan cerminan dari perilaku individu yang berada dalam suatu organisasi. Disisi lain, perubahan perilaku dapat diawali dengan perubahan budaya melalui injeksi budaya baru. Organisasi otoritas pajak, DJP dari tahun ke satu masa reformasi perpajakan ke masa reformasi lainnya mengalami perubahan yang cukup progresif dalam hal perubahan struktur organisasi dan penggunaan infrastruktur penunjang kegiatan organisasi. Namun, sangat incremental dalam hal perubahan budaya organisasi maupun gaya kepemimpinan. Fokus yang tidak bergerak jauh dari membangun kepercayaan dari masyarakat serta memperbaiki sistem pelayanan kepada masyarakat merupakan bentuk dari perubahan incremental tersebut. Meskipun demikian, perubahan tersebut tidak dalam kecepatan irama yang sama, tetapi perlu disebutkan bahwa perubahan ini merupakan salah satu respon atas adanya tuntutan untuk melakukan perubahan dari sisi internal dan eksternal. Tentu, perubahan tersebut masih memiliki berbagai catatan.

Saat ini, DJP dihadang dengan hadirnya era ekonomi digital. Adanya perubahan budaya secara signifikan yang diikuti dengan penerjemahan budaya kedalam visi, misi dan berbagai program organisasi diperlukan oleh DJP. Saat ini organisasi DJP telah membangun berbagai bentuk inisiatif sebagai langkah strategis untuk merespon era digitalisasi. Internalisasi yang konsisten merupakan pekerjaan rumah berikutnya. Hal ini akan menjadi tantangan baru yang memperlukan kepemimpinan yang kuat untuk menginjeksi organisasi dengan budaya baru yang sedang dibentuk. Hingga saat ini, DJP masih dalam on going process menuju suatu organisasi yang profesional dan memiliki persepsi dan kepercayaan yang baik dari masyarakat.

\section{Saran}

Dalam transformasi budaya organisasi yang baru yang modern, DJP perlu mengupayakan budaya organisasi yang adaptable dengan lingkungan sekitar dengan terbentuknya organisasi yang bersifat pembelajar (learning organization). Inisiatif transformasi kelembagaan yang telah ada perlu dilakukan monitoring dan evaluasi secara berkala. Modernisasi dengan penetrasi budaya baru sebaiknya menjadi perhatian penting selain penggunaan teknologi yang sophisticated dan perubahan dan perombakan struktur organisasi.

\section{DAFTAR PUSTAKA}

Adoe A, Tambunan M. 2018. Indonesia: Export of Services, Value Added Tax and Double Taxation Issue, Journal of International Taxation September 2018.

Brown A. 1998. Organization Culture, 2nd Edition, London: Prentice Hall.

Chuenjit P. 2014. The culture of taxation: definition and conceptual approaches for tax administration. Journal of Population and Social Studies 22(1), 14-34.

Deloitte. 2015. Industry 4.0, Challenges and Solutions for the Digital Transformation and Use of Exponential Technologies. Zurich: Deloitte.

Fabio BP, Hubeis M, Puspitawati H. 2016. Pengaruh gaya kepemimpinan, motivasi kerja terhadap komitmen organisasi yang berimplikasi pada kinerja karyawan. Jurnal Aplikasi Bisnis dan Manajemen 2(1): 91-104. https://doi. org/10.21070/jbmp.v2i2.1096.

Farida A. 2017. Misteri kepatuhan pajak. Akuntabel 14(2): 122-128. https://doi.org/10.29264/jakt. v14i2.1908.

Goran J, Ramesh S, Laura L. 2017. Culture for a Digital Age.https://www.mckinsey.com/businessfunctions/digital-mckinsey/our-insights/culturefor-a-digital-age [July 2017].

Gunadi. 2004. Reformasi Administrasi Perpajakan dalam Rangka Kontribusi Menuju Good Governance, Pidato Pengukuhan Guru Besar Perpajakan, FISIP Universitas Indonesia. Jakarta: UI-Press.

Huda K, Ninis N, Kamarudin. 2017. Problem of transfer pricing in indonesia taxation system. 
International Journal of Economics and Financial Issues 7(4): 139-143.

James S. 2016. The international conference on tax administration review. Journal of Tax Administration 2(2):109-119.

Leviner S. 2008. An overview: a new era of tax enforcement - from "big stick" to responsive regulation. Regulation \& Governance 2(3): 360-380.https://doi.org/10.1111/j.17485991.2008.00039.x

Lipniewicz R. 2017. Tax administration and risk management in the digital ages. Information System in Management 6(1): 26-37. https://doi. org/10.22630/ISIM.2017.6.1.3.

Mukhlis I, Utomo SH, Soesetio Y. 2015. role of taxation education on taxation knowledge and its effect on tax fairness as well as tax compliance on handicraft SMEs sectors in Indonesia. International Journal of Financial Research 6(4): 161-169. https://doi.org/10.5430/ijfr. v6n4p161.

Nurmantu S. 2008. Budaya Organisaasi, Dari Chester I Banard ke Michael E. Porter, Depok: Departemen Ilmu Administrasi FISIP UI.

Peter MS. 2006. The Fifth Discipline. USA: The Art \& Practice of the Learning Organization

Putra E. 2013. Indonesia tax return policy in the perspective of revenue, equity and efficiency. Journal of East Asian Studies 11(3).

Rahayu N. 2010. Evaluasi regulasi atas praktik penghindaran pajak penanaman modal asing. Jurnal Akuntansidan Keuangan Negara 7(1):6178. https://doi.org/10.21002/jaki.2010.04.

Ratmono D, Cahyonowati N. 2016. Kepercayaan terhadap otoritas pajak sebagai pemoderasi pengaruh deterrance factors terhadap kepatuhan wajib pajak pribadi. Jurnal Akuntansi Indonesia 2(1):1-15. http://dx.doi.org/10.30659/jai.2.1.1-
15.

Salim I. 2014. Exponential Organization: Why New Organization are Ten Times Better, Faster and Cheaper than Yours?. Canada: Singurality University Diversion Publishing.

Schein E.1991. Organization Culture and Leadership, $3 r d$ Ed. USA: John Wiley \& Son Inc.

Setyowati MS, Chandra F, Khodariah L. 2016. Organizational Transformation of Indonesian Tax Administration Authority. https://www. business.unsw.edu.au/About-Site/SchoolsSite/Taxation-Business-Law-Site/Documents/ Organizational_Transformation_of_Indonesian. pdf. [July 2017].

Tanko MB. 2015. Tax law enforcement: practice and procedure. Research Journal of Finance and Accounting 6(7):143-147.

Hadini AU, Lituhayu D, Lestari H. 2012. Perubahan sistem organisasi perpajakan di kantor direktorat jenderal pajak studi kasus Kantor Pelayanan Pajak Semarang. Indonesia Journal of Public Policy and Management Review 1(1):1-11.

Widia IN. 2017. Mengubah Paradigma Masyarakat terhadap Pajak. Jakarta: Lembaga Edukasi dan Advokasi Pajak.

Willcoxson L, Millet B. 2000. The management of organization culture. Australian Journal of Management and Organization Behaviour 3(2): 91-99.

Wong RMK, Lo AWY. 2015. Can education improve tax compliance? Evidence from different forms of tax education. http://commons.ln.edu.hk/ hkibswp/93 [July 2017].

Yulianto, Hartijasti.2014.Pengaruh gayakepemimpinan terhadap kepuasan kerja (studi kasus pada pegawai Kantor Pusat Direktorat Jenderal Pajak). Working Paper Departement Manajemen Fakultas Ekonomi Universitas Indonesia 1-11. 